\title{
Effect of Photosynthetic Photon Flux and Temperature on Floral Evocation and Development in the Vernalization-sensitive Ornamental Perennial Salvia Xsuperba 'Blaukönigin'
}

\author{
Grete Waaseth ${ }^{1}$ \\ Bioforsk Centre for Horticulture and Urban Greening Research, N-4353 Klepp stasjon, Norway \\ Roar Moe \\ Department of Plant and Environmental Sciences, Norwegian University of Life Sciences, N-1432 Ås, \\ Norway
}

Royal D. Heins

Department of Horticulture, Michigan State University, East Lansing, MI 48824-1325

Svein O. Grimstad

Bioforsk Centre for Horticulture and Urban Greening Research, N-4353 Klepp stasjon, Norway

AdDitional INDEX wORDs. flowering, PPF, photothermal ratio, PTR, photoperiod

\begin{abstract}
Varying photothermal ratios (PTR) were supplied to Salvia xsuperba Stapf 'Blaukönigin' during pre-inductive vegetative development with the exception of a short germination period under uniform conditions. In addition, both unvernalized plants and plants receiving a saturating vernalization treatment of 6 weeks at $5^{\circ} \mathrm{C}$ were given two photosynthetic photon flux $(P P F)$ levels $\left(50\right.$ or $\left.200 \mu \mathrm{mol} \cdot \mathrm{m}^{-2 \cdot} \mathrm{s}^{-1}\right)$ during subsequent inductive 16-hour long days. There were no effects of PTR treatments during vegetative development on subsequent flowering. However, the higher $P P F$ level during inductive long days significantly accelerated floral evocation in unvernalized plants, lowering the leaf number at flowering. The effect was practically negligent after the vernalization requirement was saturated. In a second experiment, varying periods $\left(4,7,10\right.$, and 14 days or until anthesis) at a $P P F$ of $200 \mu \mathrm{mol} \cdot \mathrm{m}^{-2} \cdot \mathrm{s}^{-1} \mathrm{during} 20$-hour days were given at the beginning of a long-day treatment, either with or without preceding vernalization treatment. Flowering percentage increased considerably as the period at $200 \mu \mathrm{mol} \cdot \mathrm{m}^{-2} \cdot \mathrm{s}^{-1}$ was extended compared with plants grown at a lower $P P F$ of $50 \mu \mathrm{mol} \cdot \mathrm{m}^{-2} \cdot \mathrm{s}^{-1}$. However, the leaf number on flowering plants was not affected, except in unvernalized plants receiving the highest $P P F$ continuously until anthesis, where leaf number was reduced by almost $50 \%$. We propose that the $P P F$-dependent flowering is facilitated either by the rate of ongoing assimilation or rapid mobilization of stored carbohydrates at the time of evocation. Abortion of floral primordia under the lower PPF (50

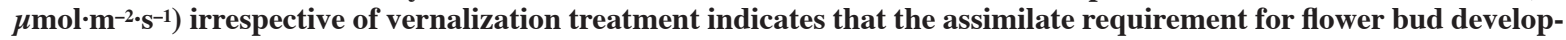
ment is independent of the mechanism for floral evocation.
\end{abstract}

Floral evocation is promoted by high photosynthetic photon flux $(P P F)$ in some, but not all herbaceous plant species. In plants that show a facultative vernalization response, flowering seems particularly sensitive to the prevailing light level when no or suboptimal vernalizing conditions are provided (Bagnall, 1992; Cremer et al., 1998; Napp-Zinn, 1984; G. Waaseth, R. Moe, and S.O. Grimstad, unpublished).

Some authors report contrasting effects of $P P F$ given prior to a saturating vernalization treatment on the subsequent transition to flowering. In Cardamine pratensis L., decreasing light level before a 5-week vernalization treatment resulted in a strong decrease in flowering percentage. However, the mean number of days to visible

Received for publication 28 Apr. 2005. Accepted for publication 31 Mar. 2006. Acknowledgments: This study received financial support from the Norwegian Crop Research Institute, Særheim Research Centre. We thank Dr. scient. Trond Rafoss (The Norwegian Crop Research Institute) for his advice regarding statistical analysis. We are also grateful to the research technicians in the greenhouses at Michigan State University and Særheim Research Centre for their efforts.

${ }^{1}$ Corresponding author. Mailing address: Bioforsk Centre for Horticulture and Urban Greening Research, Postvegen 213, N-4353 Klepp st., Norway; e-mail: grete.waaseth@bioforsk.no; phone: +47 51789820; fax: +47 51789801. bud on flowering plants was practically unaffected by the light level (Pierik, 1967a). Similar experiments with Lunaria annua L. showed no promoting effect of additional light before vernalization, although earlier experiments indicated a high light level as beneficial (Pierik, 1967b). Plants of the Arabidopsis thaliana (L.) Heynh. late-flowering ecotype Stockholm flowered up to 9 $\mathrm{d}$ earlier when the light quantity from fluorescent tubes prior to vernalization was reduced from 550 to $200 \mathrm{~W} \cdot \mathrm{m}^{-2}$ (equals about 240 and $100 \mu \mathrm{mol} \cdot \mathrm{m}^{-2} \cdot \mathrm{s}^{-1}$, respectively) provided plants were illuminated ( $P P F$ not specified) during vernalization (Napp-Zinn, 1960). When plants were vernalized in darkness, no such effect of light level during vegetative development could be seen on flowering time. High daily light integral (DLI) prior to vernalization seems to limit evocation in Lavandula angustifolia Mill. 'Hidcote Blue' and Aquilegia xhybrida Sims 'Remembrance' (Niu et al., 2002). More plants flowered and after fewer days when given 4 $\mathrm{mol} \cdot \mathrm{m}^{-2} \cdot \mathrm{d}^{-1}$ rather than $14 \mathrm{~mol} \cdot \mathrm{m}^{-2} \cdot \mathrm{d}^{-1}$ before vernalization. The authors suggest that different light quality between the two DLI treatments may have interfered with the results. The high DLI was obtained by supplementing natural light with high-pressure sodium lamps. In the same experiment, flowering in Coreopsis 
grandiflora Hogg ex Sweet. 'Sunray' was unaffected by the prevernalization light level.

In addition to these reported effects of light level, some studies also indicate that growing temperature during vegetative growth prior to vernalization might influence subsequent flowering after a saturating cold treatment. In a study by Brewster (1985), investigating joint effects of $P P F$ and temperature in Allium cepa $\mathrm{L}$., seedlings raised at $17^{\circ} \mathrm{C}$ and $600 \mu \mathrm{mol} \cdot \mathrm{m}^{-2} \cdot \mathrm{s}^{-1}$ (equals $\left.25.9 \mathrm{~mol} \cdot \mathrm{m}^{-2} \cdot \mathrm{d}^{-1}\right)$ prior to vernalization showed a higher percent inflorescence initiation and a slightly lower leaf number under the flower buds than plants raised at $2{ }^{\circ} \mathrm{C}$ and $200 \mu \mathrm{mol} \cdot \mathrm{m}^{-2 \cdot} \mathrm{s}^{-1}$ (equals $8.6 \mathrm{~mol} \cdot \mathrm{m}^{-2} \cdot \mathrm{d}^{-1}$ ). In C.pratensis (Pierik, 1967a), flowering percentage was higher, and time to visible bud was shorter when temperatures during a 5-week period prior to a saturating vernalization treatment were below $15^{\circ} \mathrm{C}$ compared to 18 to $24{ }^{\circ} \mathrm{C}$. On the other hand, in the case of $C$. pratensis, temperatures below 15 ${ }^{\circ} \mathrm{C}$ may have contributed to the vernalization response.

Both light level and temperature conditions prior to the vernalization treatment may have a significant effect on plant size or potential amount of assimilate supply available for floral organ initiation and development. Liu and Heins (1998, 2002) have shown that within a temperature range close to optimum for plant growth, biomass accumulation in Euphorbia pulcherrima Willd. Ex Klotzsch. 'Freedom' was correlated with the ratio of radiant to thermal energy, the so-called photothermal ratio. Radiant energy was defined as daily light integral and thermal energy as thermal time above the base temperature. Increasing the PTR resulted in increased plant dry weight and improved overall plant quality. PTR is not known to influence the transition to flowering in the vernalization-insensitive short-day plant E. pulcherrima. However, in vernalization-responsive species, the reports of light and temperature effects during vegetative development prior to vernalization on subsequent floral evocation suggest involvement of PTR (Brewster, 1985; Pierik, 1967a).

An earlier study with the facultative vernalization-requiring plant S. ×superba 'Blaukönigin' shows that the transition to flowering in unvernalized plants is promoted by a $P P F$ of 200 compared to $50 \mu \mathrm{mol} \cdot \mathrm{m}^{-2} \cdot \mathrm{s}^{-1}$ during forcing (G. Waaseth, R. Moe, and S.O. Grimstad, unpublished). However, light intensities in the range of 50 to $200 \mu \mathrm{mol} \cdot \mathrm{m}^{-2} \cdot \mathrm{s}^{-1}$ (equal to 3.6 and $14.4 \mathrm{~mol} \cdot \mathrm{m}^{-2} \cdot \mathrm{d}^{-1}$ ) had no influence on the transition to flowering following a saturating vernalization treatment of 6 weeks at $5{ }^{\circ} \mathrm{C}$.

Two experiments are reported here. Experiment 1 investigates whether PTR during vegetative development in noninductive conditions affects subsequent transition to flowering. This was investigated in both unvernalized plants and after a saturating vernalization treatment followed by forcing at two different light levels. Experiment 2 investigates whether short periods of elevated $P P F$ promote floral evocation to the same extent as a constant high $P P F$ level throughout forcing. Both experiments were conducted on $S$. xsuperba.

\section{Materials and Methods}

Two experiments were conducted. Plants of $S$. ×superba 'Blaukönigin'were propagated from commercial seeds obtained from Jelitto Staudensamen GmbH, Schwarmstedt, Germany. The growing medium was a peat-perlite (4:1) mixture by volume in both trials and the plants were overhead irrigated as needed with nutrient solution, which content is specified below.

Expt. 1 was conducted in greenhouses and growth chambers at Michigan State University, East Lansing, between Nov. 2001 and May 2002. Salvia $\times$ superba was seed propagated in flats and placed in a greenhouse at $23{ }^{\circ} \mathrm{C}$ air temperature setting, a 10 -h photoperiod, and $50 \%$ shade; average $P P F$ was measured to $30 \mu \mathrm{mol} \cdot \mathrm{m}^{-2} \cdot \mathrm{s}^{-1}$. After $10 \mathrm{~d}$, uniform plants were selected and transplanted into 50-cell plug trays and the temperature was lowered to $20{ }^{\circ} \mathrm{C}$. Four days later, the plants were placed in growth chambers with 10-h photoperiod and randomly assigned to different PTR treatments consisting of a combination of three temperature levels $\left(20,23\right.$, and $26^{\circ} \mathrm{C}$ and $5^{\circ} \mathrm{C}$ base temperature) and four $P P F$ regimes, 50, 100, 200, and $300 \mu \mathrm{mol} \cdot \mathrm{m}^{-2} \cdot \mathrm{s}^{-1}$ (equal to $1.8,3.6,7.2$ and $10.8 \mathrm{~mol} \cdot \mathrm{m}^{-2} \cdot \mathrm{d}^{-1}$, respectively). The plants had one pair of fully developed true leaves when the PTR treatments were initiated.

The light source in the chambers was cool white fluorescent tubes (VHOF96T12/CW/VHO; Koninklijke Philips Electronics, Eindhoven, The Netherlands) enriched with 60-W incandescent lamps, $8 \%$ of input wattage (Osram Sylvania, Danvers, Mass.). When the plants had developed an average of 10 true leaves (after 25-39 d under these conditions depending on temperature treatment), 24 plants from each PTR treatment were given vernalization treatments of $0,1.5,3$, or 6 weeks at $5^{\circ} \mathrm{C}, 10$-h photoperiods and an average $P P F$ of $20 \mu \mathrm{mol} \cdot \mathrm{m}^{-2} \cdot \mathrm{s}^{-1}$ from fluorescent lamps. The plants were then potted in $10-\mathrm{cm}$-diameter, $0.55-\mathrm{L}$ round plastic pots and placed in the greenhouse at $20{ }^{\circ} \mathrm{C}$ temperature setting, 16-h photoperiod, and two PPF treatments (200 and $50 \mu \mathrm{mol} \cdot \mathrm{m}^{-2} \cdot \mathrm{s}^{-1}$ on average). Twelve plants per treatment were used and the final registration was taken after $100 \mathrm{~d}$ in forcing conditions. The $P P F$ of $200( \pm 122) \mu \mathrm{mol} \cdot \mathrm{m}^{-2} \cdot \mathrm{s}^{-1}$ (equal to 11.5 $\left.\mathrm{mol} \cdot \mathrm{m}^{-2} \cdot \mathrm{d}^{-1}\right)$ was created by supplementing natural irradiation with high-pressure sodium lamps for $16 \mathrm{~h} \cdot \mathrm{d}^{-1}$. The variability was \pm 122 $\mu \mathrm{mol} \cdot \mathrm{m}^{-2} \cdot \mathrm{s}^{-1}$. The lower PPF of $50 \pm 67 \mu \mathrm{mol} \cdot \mathrm{m}^{-2} \cdot \mathrm{s}^{-1}$ (equal to $\left.2.9 \mathrm{~mol} \cdot \mathrm{m}^{-2} \cdot \mathrm{d}^{-1}\right)$ was achieved by hanging a double layer of $35 \%$ greenhouse shade cloth (PLS 30; Ludvig Svensson, Charlotte, N.C.) beneath the high-pressure sodium lamps. Infrared heaters were added below the shade cloth to eliminate the difference in radiant energy between the two $P P F$ treatments. A data-logger constantly monitored plant temperature using thermocouples inserted into the main shoot close to the apex. The data-logger was programmed to turn the heaters on and off every $10 \mathrm{~s}$ as plant temperature under the shade cloth dropped below or rose above the plant temperature of unshaded plants. Two different thermocouples monitored plant temperature in each treatment (average and maximum temperature deviation was 0.07 and 0.96 ${ }^{\circ} \mathrm{C}$, respectively). Plants were fertilized at every irrigation with a nutrient solution of well water [electrical conductivity (EC) of $\left.0.70 \mathrm{dSm}{ }^{-1}, 105 \mathrm{mg} \cdot \mathrm{L}^{-1} \mathrm{Ca}, 35 \mathrm{mg} \cdot \mathrm{L}^{-1} \mathrm{Mg}, 85 \mathrm{mg} \cdot \mathrm{L}^{-1} \mathrm{~S}\right]$ acidified with $\mathrm{H}_{2} \mathrm{SO}_{4}$ to a titratable $\mathrm{CaCO}_{3}$ alkalinity of $130 \mathrm{mg} \cdot \mathrm{L}^{-1}$ and added water-soluble fertilizer in the amount of $125 \mathrm{mg} \cdot \mathrm{L}^{-1} \mathrm{~N}, 12$ $\mathrm{mg} \cdot \mathrm{L}^{-1} \mathrm{P}, 125 \mathrm{mg} \cdot \mathrm{L}^{-1} \mathrm{~K}, 13 \mathrm{mg} \cdot \mathrm{L}^{-1} \mathrm{Ca}, 1.0 \mathrm{mg} \cdot \mathrm{L}^{-1} \mathrm{Fe}, 0.5 \mathrm{mg} \cdot \mathrm{L}^{-1}$ $\mathrm{Mn}, 0.5 \mathrm{mg} \cdot \mathrm{L}^{-1} \mathrm{Zn}, 0.5 \mathrm{mg} \cdot \mathrm{L}^{-1} \mathrm{Cu}, 0.1 \mathrm{mg} \cdot \mathrm{L}^{-1} \mathrm{~B}, 0.1 \mathrm{mg} \cdot \mathrm{L}^{-1} \mathrm{Mo}$ (MSU Special; Greencare Fertilizers, Chicago).

Expt. 2 was conducted in growth chambers at Saerheim Research Centre in Klepp, Norway, between Oct. 2002 and May 2003 and replicated in Feb.-Sept. 2003.

The light source in the chambers was cool white fluorescent tubes (TLD33 standard white; Koninklijke Philips Electronics) enriched with incandescent light, $8 \%$ of input wattage. All PPF measurements were made at plant level with a quantum sensor (Li-185 B; LI-COR Biosciences, Lincoln, Nebr.). Salvia $\times$ superba was seed propagated in flats and placed in a growth chamber at $22{ }^{\circ} \mathrm{C}$ air temperature, a $10-\mathrm{h}$ photoperiod, and a $P P F$ of 100 $\mu \mathrm{mol} \cdot \mathrm{m}^{-2} \cdot \mathrm{s}^{-1}$. After $10 \mathrm{~d}$, the plants were transplanted into 56-cell 
plug trays and the temperature was lowered to $20^{\circ} \mathrm{C}$. Vernalization treatments of zero (unvernalized), or 6 weeks (saturating cold treatment) at $5{ }^{\circ} \mathrm{C}$ and a $P P F$ of $30 \mu \mathrm{mol} \cdot \mathrm{m}^{-2} \cdot \mathrm{s}^{-1}$ were initiated when the plants had developed an average of 10 true leaves (after $52 \mathrm{~d}$ ). Uniform plants of both unvernalized and cold-treated plants were selected, potted in $10-\mathrm{cm}$-diameter, $0.55-\mathrm{L}$ round plastic containers, given inductive long photoperiods of $20 \mathrm{~h}$, and randomly assigned to treatments of different periods at 200 $\mu \mathrm{mol} \cdot \mathrm{m}^{-2} \cdot \mathrm{s}^{-1}$ (equal to $14.4 \mathrm{~mol} \cdot \mathrm{m}^{-2} \cdot \mathrm{d}^{-1}$ ) as follows. Groups of six plants spent the initial $0,4,7,10$, or 14 inductive long days at the highest $P P F$ level, after which they were moved to $50 \mu \mathrm{mol} \cdot \mathrm{m}^{-2 \cdot} \mathrm{s}^{-1}$ (equal to $3.6 \mathrm{~mol} \cdot \mathrm{m}^{-2} \cdot \mathrm{d}^{-1}$ ) to complete the floral development. In addition, one group stayed at the highest $P P F$ until the first open flower, spending the entire period of forcing in long days at 200 $\mu \mathrm{mol} \cdot \mathrm{m}^{-2} \cdot \mathrm{s}^{-1}$. The group that spent $0 \mathrm{~d}$ at the highest $P P F$ received a constant $50 \mu \mathrm{mol} \cdot \mathrm{m}^{-2} \cdot \mathrm{s}^{-1}$ throughout development in inductive long days. The shift between $P P F$ treatments was facilitated by moving the plants between two adjacent growth chambers kept at a constant 200 and $50 \mu \mathrm{mol} \cdot \mathrm{m}^{-2} \cdot \mathrm{s}^{-1}$, respectively.

The air temperature setting and airflow in the chambers was adjusted to attain a plant temperature of $20^{\circ} \mathrm{C}$ in all treatments, measured with a hand held infrared thermometer (TFI 497; Ebro Electronic GmbH \& Co. KG, Ingolstadt, Germany) Maximum air flow rate was $786 \mathrm{~m}^{3} \cdot \mathrm{h}^{-1}\left(27.12-\mathrm{m}^{3}\right.$ chambers $)$. The nutrient solution used contained $250 \mathrm{mg} \cdot \mathrm{L}^{-1} \mathrm{~N}, 47 \mathrm{mg} \cdot \mathrm{L}^{-1} \mathrm{P}, 313 \mathrm{mg} \cdot \mathrm{L}^{-1}$ $\mathrm{K}, 195 \mathrm{mg} \cdot \mathrm{L}^{-1} \mathrm{Ca}, 37 \mathrm{mg} \cdot \mathrm{L}^{-1} \mathrm{Mg}, 48 \mathrm{mg} \cdot \mathrm{L}^{-1} \mathrm{~S}, 2.09 \mathrm{mg} \cdot \mathrm{L}^{-1} \mathrm{Fe}$, $0.93 \mathrm{mg} \cdot \mathrm{L}^{-1} \mathrm{Mn}, 0.25 \mathrm{mg} \cdot \mathrm{L}^{-1} \mathrm{~B}, 0.23 \mathrm{mg} \cdot \mathrm{L}^{-1} \mathrm{Zn}, 0.08 \mathrm{mg} \cdot \mathrm{L}^{-1} \mathrm{Cu}$, and $0.03 \mathrm{mg} \cdot \mathrm{L}^{-1} \mathrm{Mo}$.

Data Collection ANd anAlysis. Number of flowering plants, total number of true leaves initiated under the first flower on the main shoot, and date of macroscopic appearance of the first flower bud was registered in both experiments. In Expt. 2, some of the plants reverted to vegetative growth resulting in macroscopically observable blind shoots, a process referred to as abortion or blasting. The number of generative plants was therefore calculated in this experiment by adding the recorded number of flowering plants and the number of plants with blind shoots.

The long-day developmental time (FT) is designated by the number of days from the initial inductive long day to the first visible bud. The developmental stage at evocation is recorded by counting the total number of leaves (LN) under the first visible bud on the main shoot. Leaf unfolding rate (LUR) in leaves per day was computed for both vegetative growth in short days and the forcing period from the initial long day to the first visible bud.

PTR during vegetative growth in short days was calculated from temperature and $P P F$ settings, and the length of the growing period (Table 1). Expt. 1 was arranged as a split-split-split-plot with 12 replicate plants per treatment. Expt. 2 was a split plot with vernalization as main-plot factor in a complete randomized design and six replicate plants per treatment. Expt. 2 was repeated once. Statistical analyses were performed using the GLM and LOGISTIC procedures and mean separation by Student-Newman-Keuls test $(P=0.05)$ of SAS (version 8.2 for Windows; SAS Institute GmbH, Heidelberg, Germany).

\section{Results}

\section{Expt. 1}

RATE OF VEGETATIVE DEVELOPMENT IN SHORT DAYS. The PTR treatments were applied for as long as it took the plants to develop eight true leaves. The plants grown under $26^{\circ} \mathrm{C}$ completed the vegetative development in $25 \mathrm{~d}$ in this experiment, $14 \mathrm{~d}$ earlier than the plants grown at $20^{\circ} \mathrm{C}$, corresponding to a LUR of 0.40 and 0.26 leaves/d, respectively. The plants did not develop macroscopically visible additional leaves during the cold treatment.

RATE OF DEVElopment IN INDUCTIVE LONG DAYS. The developmental time in long days was closely correlated with the number of leaves that were initiated after the beginning of the long-day treatment (Fig. 1). Furthermore, the LUR for leaves developed during the long-day forcing prior to evocation was not significantly different at 200 and $50 \mu \mathrm{mol} \cdot \mathrm{m}^{-2} \cdot \mathrm{s}^{-1}(0.42$ and 0.40 leaves/d, respectively). The average difference in plant temperature between the two $P P F$ treatments was $0.96{ }^{\circ} \mathrm{C}$ when infrared heaters were not used. The heaters reduced the temperature difference to $0.07^{\circ} \mathrm{C}$.

EFFECT OF PTR dURING VEGETATIVE DEVELOPMENT ON FLOWERING. Neither flowering percentage nor leaf number correlated with the calculated PTR during vegetative development, irrespective of whether or not the plants were vernalized (Fig. 2). The sudden drop in flowering percentage at a PTR of 0.17 after 6 weeks of cold is the result of an incident in the cooler where some plants were impaired due to a combination of low light level (20

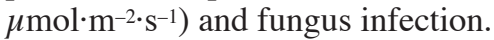

Table 1. Photothermal ratio during vegetative development calculated from air temperature and $P P F$ settings, and an assumed base temperature of $5^{\circ} \mathrm{C} .{ }^{\mathrm{z}}$

\begin{tabular}{|c|c|c|c|c|c|c|}
\hline $\begin{array}{l}\text { Air temp } \\
\text { setting }\left({ }^{\circ} \mathrm{C}\right)\end{array}$ & $\begin{array}{c}\text { Daily } \\
\text { thermal time } \\
\text { (degree-days/d) }\end{array}$ & $\begin{array}{l}\text { Cumulative } \\
\text { thermal time } \\
\text { (degree-days) }\end{array}$ & $\begin{array}{c}\text { PPF setting } \\
\left(\mu \mathrm{mol} \cdot \mathrm{m}^{-2} \cdot \mathrm{s}^{-1}\right)\end{array}$ & $\begin{array}{c}\text { Daily } \\
\text { light integral } \\
\left(\mathrm{mol} \cdot \mathrm{m}^{-2} \cdot \mathrm{d}^{-1}\right)\end{array}$ & $\begin{array}{c}\text { Cumulative } \\
\text { light integral } \\
\left(\mathrm{mol} \cdot \mathrm{m}^{-2}\right)\end{array}$ & $\begin{array}{l}\text { Photothermal ratio } \\
\left(\mathrm{mol} / \text { degree-day } / \mathrm{m}^{2}\right)\end{array}$ \\
\hline \multirow[t]{4}{*}{26} & 21 & 525 & 300 & 10.8 & 270 & 0.51 \\
\hline & & & 200 & 7.2 & 180 & 0.34 \\
\hline & & & 100 & 3.6 & 90 & 0.17 \\
\hline & & & 50 & 1.8 & 45 & 0.09 \\
\hline \multirow[t]{4}{*}{23} & 18 & 576 & 300 & 10.8 & 346 & 0.60 \\
\hline & & & 200 & 7.2 & 230 & 0.40 \\
\hline & & & 100 & 3.6 & 115 & 0.20 \\
\hline & & & 50 & 1.8 & 58 & 0.10 \\
\hline \multirow[t]{4}{*}{20} & 15 & 585 & 300 & 10.8 & 421 & 0.72 \\
\hline & & & 200 & 7.2 & 280 & 0.48 \\
\hline & & & 100 & 3.6 & 140 & 0.24 \\
\hline & & & 50 & 1.8 & 70 & 0.12 \\
\hline
\end{tabular}

zThe exact base temperature in this species has not been determined, hence we assumed a base temperature of $5^{\circ} \mathrm{C}$, which is commonly used in similar experiments with other species. 

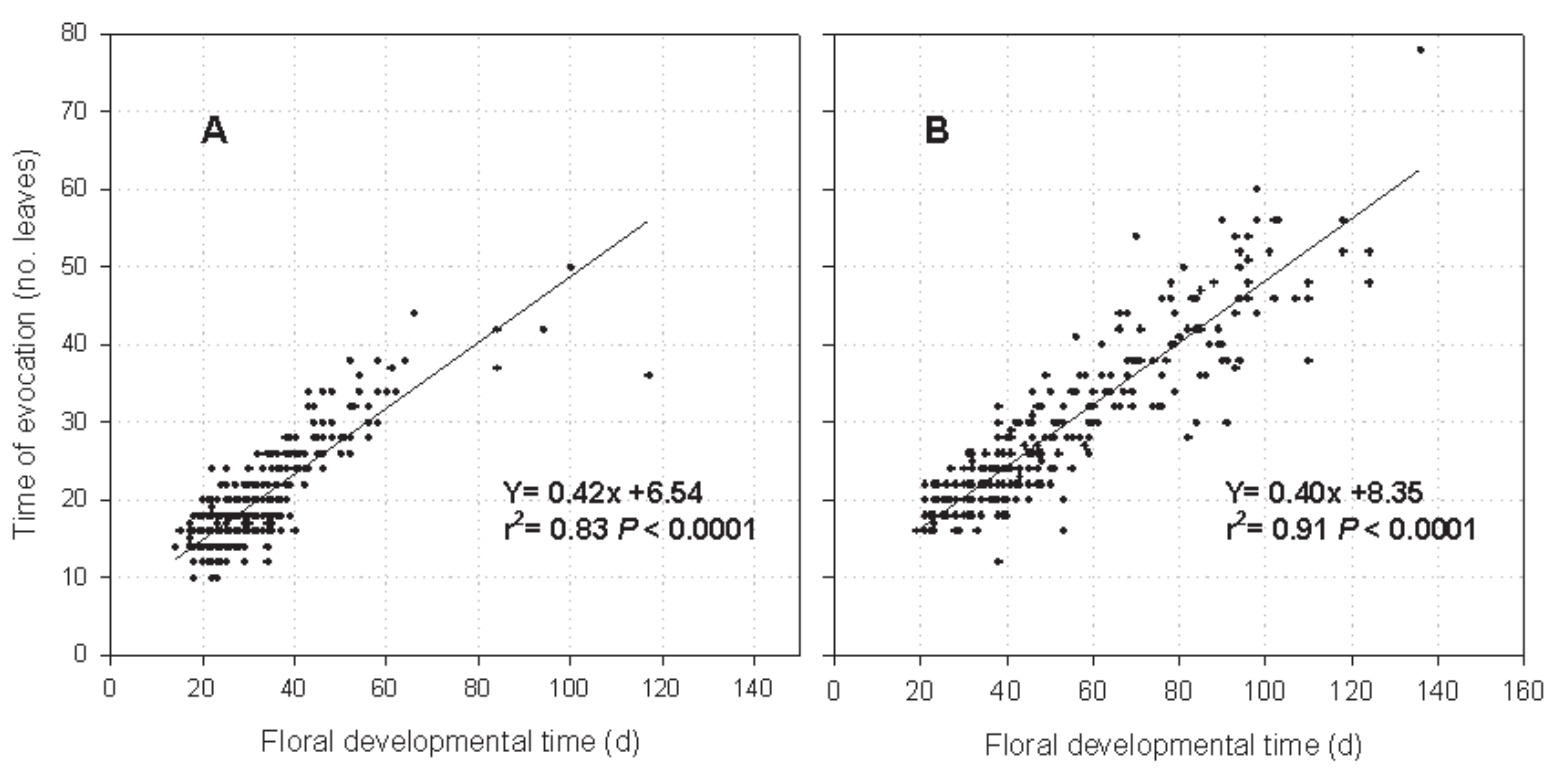

Fig. 1. Number of true leaves initiated under the first visible flower on the main shoot in Salvia $\times$ superba 'Blaukönigin' in relation to developmental time (days from the initial inductive long-day to the first visible flower bud). (A) $200 \mu \mathrm{mol} \cdot \mathrm{m}^{-2} \cdot \mathrm{s}^{-1} P P F$; (B) $50 \mu \mathrm{mol} \cdot \mathrm{m}^{-2} \cdot \mathrm{s}^{-1} P P F$. Data are pooled for plants previously grown under different photothermal ratio treatments, ranging from 0.09 to $0.72 \mathrm{~mol} / \mathrm{degree}-\mathrm{day} / \mathrm{m}^{2}$.

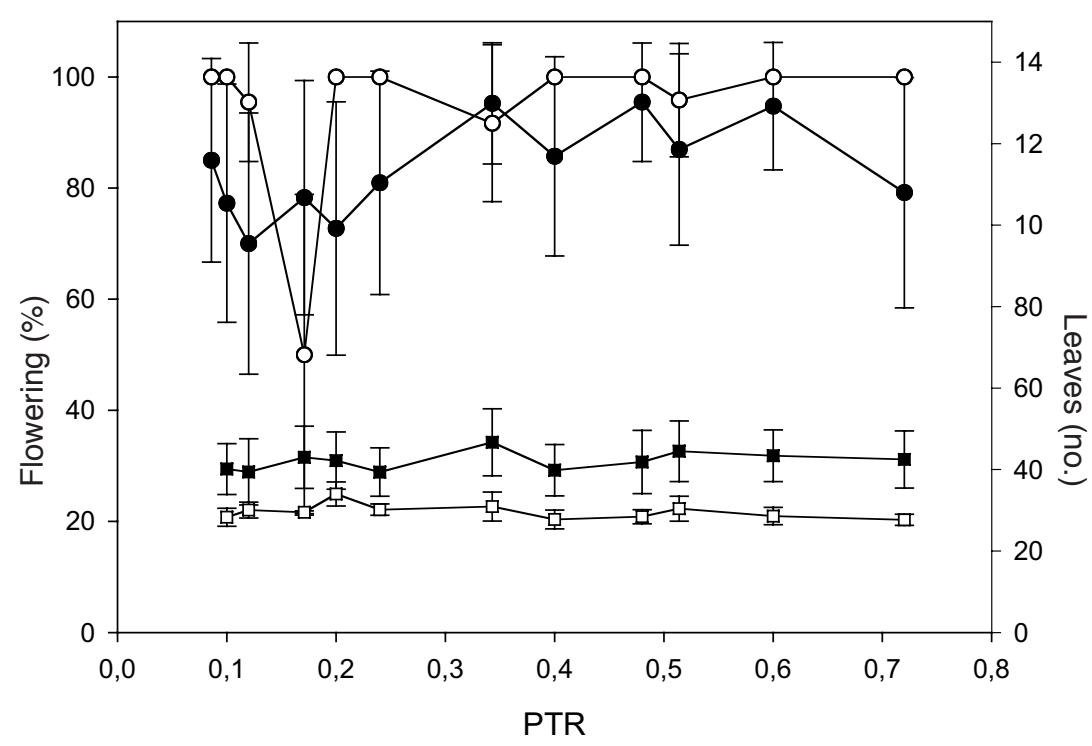

Fig. 2. Effect of photothermal ratio (PTR) during vegetative development on flowering percentage $(\mathrm{O} / \mathbf{O})$ and number of true leaves initiated under the first flower on the main shoot $(\square / \square)$ after 0 weeks $(\square / O)$ or 6 weeks $(\square / O)$ of vernalization in Salvia $\times$ superba 'Blaukönigin.' Data includes plants grown at two $P P F$ levels $\left(50\right.$ or $\left.200 \mu \mathrm{mol} \cdot \mathrm{m}^{-2} \cdot \mathrm{s}^{-1}\right)$ during forcing.

Nevertheless, increasing the $P P F$ during vegetative development in short days to $200 \mu \mathrm{mol} \cdot \mathrm{m}^{-2} \cdot \mathrm{s}^{-1}\left(7.2 \mathrm{~mol} \cdot \mathrm{m}^{-2} \cdot \mathrm{d}^{-1}\right)$ did create a moderate increase in flowering percentage, but only in unvernalized plants forced under the lower PPF (Table 2). This change was not accompanied by an increase in leaf number; thus, in spite of more plants flowering when given a higher $P P F$ in the preceding growth phase, the plants that did flower flowered at the same developmental stage. Any influence on flowering of $P P F$ during vegetative development was eliminated if the plants received $200 \mu \mathrm{mol} \cdot \mathrm{m}^{-2} \cdot \mathrm{s}^{-1}$ during forcing. The visual ornamental value of the plants at flowering was not measured; however, our photographic material indicates that PTR has little effect also in this respect (data not shown).

EFFECT OF VERNALIZATION AND PPF DURING INDUCTIVE LONG DAYS ON FLOWERING. The minor effect of PTR during vegetative growth on subsequent flowering described in the previous section was negligible compared with the substantial enhancement of flowering brought about by vernalization and elevating the $P P F$ during subsequent inductive long days (Tables 2 and 3; Fig. 3). When given 200 $\mu \mathrm{mol} \cdot \mathrm{m}^{-2} \cdot \mathrm{s}^{-1}$ during inductive long days, all plants flowered irrespective of vernalization (Fig. 3). Six weeks of cold reduced LN by 7.7 leaves, corresponding to a FT-promotion of about $14 \mathrm{~d}$ (data not shown). In contrast, number of flowering plants in the $50 \mu \mathrm{mol} \cdot \mathrm{m}^{-2} \cdot \mathrm{s}^{-1}\left(2.9 \mathrm{~mol} \cdot \mathrm{m}^{-2} \cdot \mathrm{d}^{-1}\right)$ treatment increased by $32 \%$ in response to vernalization, and developmental stage at evocation was reduced by an average 26 leaves after 6 weeks of cold compared to unchilled plants (Fig. 3), resulting in 68-d earlier flowering (data not shown). Furthermore, increasing the $P P F$ from 50 to $200 \mu \mathrm{mol} \cdot \mathrm{m}^{-2} \cdot \mathrm{s}^{-1}$ $\left(2.9-11.5 \mathrm{~mol} \cdot \mathrm{m}^{-2 \cdot} \mathrm{d}^{-1}\right)$ increased the flowering percentage in unvernalized plants by $37 \%$, and reduced the developmental stage at evocation by 24 leaves in unvernalized plants against six leaves after 6 weeks of cold, corresponding to a FT-reduction of 62 and $12 \mathrm{~d}$, respectively (Fig. 3).

Although almost all fully vernalized plants flowered at 50 $\mu \mathrm{mol} \cdot \mathrm{m}^{-2} \cdot \mathrm{s}^{-1}$ and flowering was only moderately delayed (12 d) compared with $200 \mu \mathrm{mol} \cdot \mathrm{m}^{-2} \cdot \mathrm{s}^{-1}$, the plant quality was greatly affected by $P P F$. Plants at the higher $P P F$ had a more compact growth habit and developed considerably more lateral branches and flowers per plant than at $50 \mu \mathrm{mol} \cdot \mathrm{m}^{-2} \cdot \mathrm{s}^{-1}$.

\section{Expt. 2}

The developmental stage at evocation (LN) was only margin- 
Table 2. Flowering percentage and number of true leaves initiated under the first flower on the main shoot in Salvia $\times$ superba 'Blaukönigin' in relation to $P P F$ given during vegetative phase or reproductive phase for either unvernalized plants or combined with a saturating vernalization treatment of 6 weeks at $5^{\circ} \mathrm{C}$. Values represent mean \pm SE. Data are pooled for plants grown under different temperatures $\left(20,23\right.$, or $\left.26^{\circ} \mathrm{C}\right)$ during vegetative development.

\begin{tabular}{|c|c|c|c|c|c|}
\hline \multirow{3}{*}{$\begin{array}{l}\text { Time } \\
\text { at } 5^{\circ} \mathrm{C} \\
\text { (weeks) } \\
\end{array}$} & \multirow{3}{*}{$\begin{array}{c}P P F \text { during } \\
\text { vegetative phase } \\
\left(\mu \mathrm{mol} \cdot \mathrm{m}^{-2} \cdot \mathrm{s}^{-1}\right)\end{array}$} & \multicolumn{4}{|c|}{$P P F$ during forcing $\left(\mu \mathrm{mol} \cdot \mathrm{m}^{-2} \cdot \mathrm{s}^{-1}\right)$} \\
\hline & & 50 & 200 & 50 & 200 \\
\hline & & \multicolumn{2}{|c|}{ Flowering (\%) } & \multicolumn{2}{|c|}{ Leaves (no.) } \\
\hline \multirow[t]{4}{*}{0} & 50 & $50.0 \pm 25.5 \mathrm{a}^{\mathrm{z}}$ & $100.0 \pm 0.0 \mathrm{a}$ & $59.7 \pm 4.2 \mathrm{a}$ & $32.5 \pm 2.9 \mathrm{a}$ \\
\hline & 100 & $50.1 \pm 25.4 \mathrm{a}$ & $100.0 \pm 0.0 \mathrm{a}$ & $58.6 \pm 4.2 \mathrm{a}$ & $34.7 \pm 4.4 \mathrm{a}$ \\
\hline & 200 & $82.1 \pm 19.5 \mathrm{a}$ & $100.0 \pm 0.0 \mathrm{a}$ & $58.5 \pm 4.9 \mathrm{a}$ & $32.9 \pm 3.4 \mathrm{a}$ \\
\hline & 300 & $70.0 \pm 23.3 \mathrm{a}$ & $100.0 \pm 0.0 \mathrm{a}$ & $57.2 \pm 4.7 \mathrm{a}$ & $35.4 \pm 3.9 \mathrm{a}$ \\
\hline \multirow[t]{4}{*}{6} & 50 & $96.0 \pm 1.0 \mathrm{a}$ & $100.0 \pm 0.0 \mathrm{a}$ & $32.5 \pm 1.9 \mathrm{a}$ & $26.7 \pm 1.5 \mathrm{~b}$ \\
\hline & 100 & $90.0 \pm 1.5 \mathrm{a}$ & $100.0 \pm 0.0 \mathrm{a}$ & $32.4 \pm 3.4 \mathrm{a}$ & $29.1 \pm 1.1 \mathrm{a}$ \\
\hline & 200 & $94.4 \pm 11.6 \mathrm{a}$ & $100.0 \pm 0.0 \mathrm{a}$ & $32.6 \pm 3.2 \mathrm{a}$ & $25.6 \pm 1.1 \mathrm{~b}$ \\
\hline & 300 & $97.6 \pm 8.3 \mathrm{a}$ & $100.0 \pm 0.0 \mathrm{a}$ & $31.8 \pm 2.3 \mathrm{a}$ & $26.0 \pm 1.5 \mathrm{~b}$ \\
\hline
\end{tabular}

zMean separation in columns by Student-Newman-Keuls test at $P \leq 0.05$. Vernalized and unvernalized plants are analyzed separately.

Table 3. Flowering percentage and number of true leaves initiated under the first flower on the main shoot in Salvia ×superba 'Blaukönigin' as affected by temperature during vegetative development in interaction with light level during forcing for either unvernalized plants or combined with a saturating vernalization treatment of 6 weeks at $5{ }^{\circ} \mathrm{C}$. Values represent mean $\pm \mathrm{SE}$. Data are pooled for plants grown under different $P P F\left(50,100,200\right.$, or $\left.300 \mu \mathrm{mol} \cdot \mathrm{m}^{-2} \cdot \mathrm{s}^{-1}\right)$ during vegetative development.

\begin{tabular}{|c|c|c|c|c|c|}
\hline \multirow{3}{*}{$\begin{array}{l}\text { Time } \\
\text { at } 5^{\circ} \mathrm{C} \\
\text { (weeks) }\end{array}$} & \multirow{3}{*}{$\begin{array}{c}\text { Temp during } \\
\text { vegetative phase } \\
\left({ }^{\circ} \mathrm{C}\right)\end{array}$} & \multicolumn{4}{|c|}{$P P F$ during forcing $\left(\mu \mathrm{mol} \cdot \mathrm{m}^{-2} \cdot \mathrm{s}^{-1}\right)$} \\
\hline & & 50 & 200 & 50 & 200 \\
\hline & & \multicolumn{2}{|c|}{ Flowering (\%) } & \multicolumn{2}{|c|}{ Leaves (no.) } \\
\hline \multirow[t]{3}{*}{0} & 26 & $69.2 \pm 23.4 \mathrm{a}^{\mathrm{z}}$ & $100.0 \pm 0.0 \mathrm{a}$ & $60.9 \pm 4.8 \mathrm{a}$ & $34.0 \pm 3.2 \mathrm{a}$ \\
\hline & 23 & $60.0 \pm 29.2 \mathrm{a}$ & $100.0 \pm 0.0 \mathrm{a}$ & $54.1 \pm 4.0 \mathrm{a}$ & $35.0 \pm 4.6 \mathrm{a}$ \\
\hline & 20 & $60.0 \pm 24.8 \mathrm{a}$ & $100.0 \pm 0.0 \mathrm{a}$ & $58.0 \pm 4.4 \mathrm{a}$ & $32.7 \pm 3.2 \mathrm{a}$ \\
\hline \multirow[t]{3}{*}{6} & 26 & $86.8 \pm 17.1 \mathrm{a}$ & $100.0 \pm 0.0 \mathrm{a}$ & $34.6 \pm 3.4 \mathrm{a}$ & $26.2 \pm 1.6 \mathrm{ab}$ \\
\hline & 23 & $100.0 \pm 0.0 \mathrm{a}$ & $100.0 \pm 0.0 \mathrm{a}$ & $32.2 \pm 2.2 \mathrm{a}$ & $25.3 \pm 1.3 b$ \\
\hline & 20 & $97.9 \pm 7.3 \mathrm{a}$ & $100.0 \pm 0.0 \mathrm{a}$ & $30.8 \pm 1.7 \mathrm{a}$ & $27.4 \pm 2.2 \mathrm{a}$ \\
\hline
\end{tabular}

zMean separation in columns by Student-Newman-Keuls test at $P \leq 0.05$. Vernalized and unvernalized plants are analyzed separately.

ally influenced by $P P F$ in both unvernalized plants and after a saturating vernalization treatment (Fig. 4). The tendency towards declining $\mathrm{LN}$ in response to increasing number of days at the highest $P P F$ is not statistically significant. As seen in Expt. 1, LN in unvernalized plants was greatly reduced under continuous $200 \mu \mathrm{mol} \cdot \mathrm{m}^{-2} \cdot \mathrm{s}^{-1}\left(14.4 \mathrm{~mol} \cdot \mathrm{m}^{-2 \cdot} \cdot \mathrm{d}^{-1}\right)$ until flowering.

Percentage of generative plants increased with increasing number of days of forcing at $200 \mu \mathrm{mol} \cdot \mathrm{m}^{-2} \cdot \mathrm{s}^{-1}\left(14.4 \mathrm{~mol} \cdot \mathrm{m}^{-2} \cdot \mathrm{d}^{-1}\right)$ (Table 4). Number of generative plants at $50 \mu \mathrm{mol} \cdot \mathrm{m}^{-2} \cdot \mathrm{s}^{-1}(3.6$ $\mathrm{mol} \cdot \mathrm{m}^{-2} \cdot \mathrm{d}^{-1}$ ) was low compared with our experience from earlier experiments, and in some of the plants the flower bud aborted, resulting in blind shoots (Table 4). However, there were no blind shoots in plants that were forced at a constant $200 \mu \mathrm{mol} \cdot \mathrm{m}^{-2} \cdot \mathrm{s}^{-1}$ or plants that had formed visible flower buds prior to a light reduction from 200 to $50 \mu \mathrm{mol} \cdot \mathrm{m}^{-2} \cdot \mathrm{s}^{-1}$. Flower bud abortion was equally frequent in vernalized and nonvernalized plants.

\section{Discussion}

EFFECT OF PTR DURING VEGETATIVE DEVELOPMENT ON FLOWERING. Some authors report that flowering in vernalization-responsive plants is influenced by irradiance and temperature conditions preceding vernalization(Brewster, 1985; Pierik, 1967a). Examples of positive, negative, and no effect of high light levels can be found in the literature (Napp-Zinn, 1960; Niu et al., 2002; Pierik,

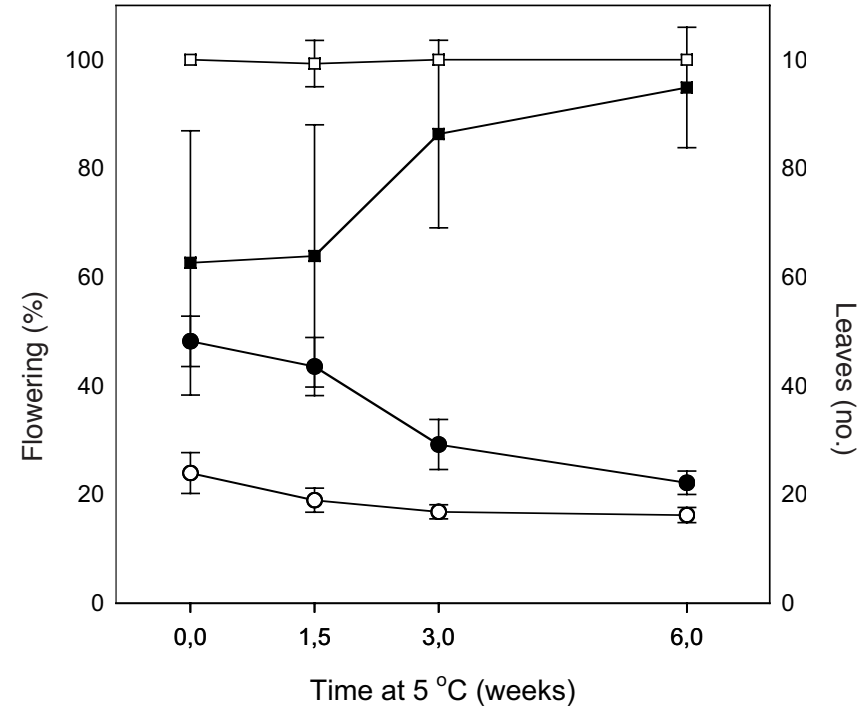

Fig. 3. The effect of vernalization $\left(0,1.5,3\right.$, and 6 weeks at $\left.5^{\circ} \mathrm{C}\right)$ and $P P F$ during forcing (20-h days) $50 \mu \mathrm{mol} \cdot \mathrm{m}^{-2} \cdot \mathrm{s}^{-1}(\mathbf{\square} / \mathbf{O}) ; 200 \mu \mathrm{mol} \cdot \mathrm{m}^{-2} \cdot \mathrm{s}^{-1}$ $(\square / \mathrm{O})$ on flowering percentage after $100 \mathrm{~d}$ of forcing $(\square / \square)$ and number of true leaves developed under the first flower on the main shoot $(\mathrm{O} / \mathrm{O})$ in Salvia ×superba 'Blaukönigin'. Data are pooled for plants previously grown under different photothermal ratio treatments, ranging from 0.09 to $0.72 \mathrm{~mol} /$ degree-day $/ \mathrm{m}^{2}$. 


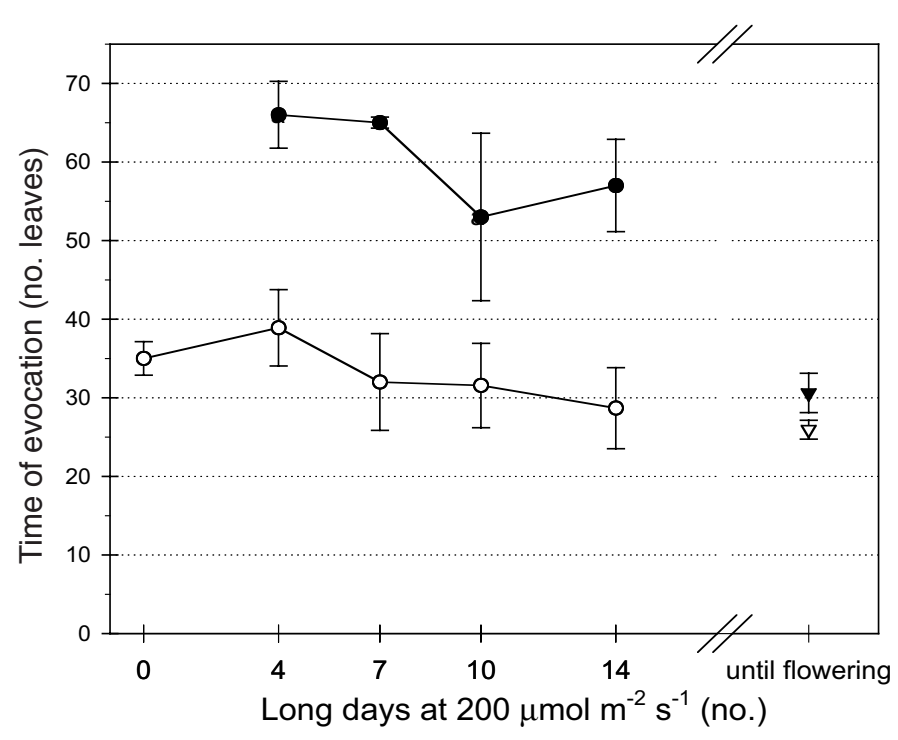

Fig. 4. Number of true leaves initiated under the first flower on the main shoot in Salvia $\times$ superba 'Blaukönigin', in response to different periods of inductive long days $(20 \mathrm{~h})$ at a $P P F$ of $200 \mu \mathrm{mol} \cdot \mathrm{m}^{-2} \cdot \mathrm{s}^{-1}$ and either 6 weeks (open symbols) or 0 weeks of vernalization (solid symbols). After $0,4,7,10$, or $14 \mathrm{~d}$ at $200 \mu \mathrm{mol} \cdot \mathrm{m}^{-2} \cdot \mathrm{s}^{-1}$, the plants were moved to $50 \mu \mathrm{mol} \cdot \mathrm{m}^{-2} \cdot \mathrm{s}^{-1}$ to complete the floral development.

1967a, 1967b). Even contradictory results within the same species were found for L. апnиa (Pierik, 1967b).

According to our results, neither light level nor temperature during vegetative development prior to vernalization has significant impact on LN in $S$. xsuperba 'Blaukönigin'. Just a very slight beneficial effect on flowering percentage could be seen in unvernalized plants from increasing the $P P F$ and only at the lower light level of $50 \mu \mathrm{mol} \cdot \mathrm{m}^{-2} \cdot \mathrm{s}^{-1}$ during forcing.

Niu et al. (2002) observed reduced flowering percentage and delayed flowering in L. angustifolia and A. xhybrida plants given high DLI $\left(14 \mathrm{~mol} \cdot \mathrm{m}^{-2} \cdot \mathrm{d}^{-1}\right)$ rather than low $\left(4 \mathrm{~mol} \cdot \mathrm{m}^{-2} \cdot \mathrm{d}^{-1}\right)$ prior to vernalization treatments. They proposed that a low red to far-red ratio created by their use of high-pressure sodium lamps as supplemental lighting in the high DLI treatment might have caused this negative flowering response. In ourexperiment, the main light source from fluorescent bulbs was enriched with incandescent light in order to reduce the red to far-red ratio. Furthermore, we found no negative effect of increasing the red to far-red ratio as high as 13.3 on the transition to flowering in unvernalized
S. ×superba 'Blaukönigin' grown at a $P P F$ of $250 \mu \mathrm{mol} \cdot \mathrm{m}^{-2} \cdot \mathrm{s}^{-1}$ and a DLI of $18.0 \mathrm{~mol} \cdot \mathrm{m}^{-2 \cdot} \cdot \mathrm{d}^{-1}$ (data not shown). Thus, the lack of response to pre-vernalization $P P F$ levels in our study compared with the varying responses reported in the literature might be due to differences between experiments regarding light quality and varying sensitivity among species towards both light quality and $P P F$ level.

Plant size is also an important factor in experiments involving effects of different temperature treatments on flowering. In our experiment, plants from different PTR-treatments were at the same 10-leaf developmental stage when they received inductive vernalization and photoperiods. Plant development is mainly dependent on temperature; thus, plants grown for the same period of time but at different temperatures will be of a different ontogenetic age. A change in $P P F$ on the other hand, seems to have only minor effects on plant ontogenetic age. It is important to consider the $P P F$-level, day length, light quality, and temperature separately as well as DLI and PTR-levels. In the study by Niu et al. (2002), all plants were grown for 5 weeks under the same temperature $\left(20 \pm 2{ }^{\circ} \mathrm{C}\right)$ and day length $(12 \mathrm{~h})$, and two different DLI-levels (4 and $14 \mathrm{~mol} \cdot \mathrm{m}^{-2 \cdot} \mathrm{d}^{-1}$ ) prior to vernalization. Technically, these treatments differ with respect to both DLI and PTR. However, since temperature and day length was kept constant, the $P P F$ was in fact the only variable that actually differed between treatments, in addition to the red to far-red ratio as discussed in the previous paragraph. The leaf numbers was similar after 5 weeks at these treatments. Thus in this case, the ontogenetic age proved to be unaffected by the light treatments for the three herbaceous perennial species studied.

The base temperature is the lowest temperature where metabolic processes result in a net biomass gain. Base temperature has not been assessed for $S$. ×superba 'Blaukönigin'; $5{ }^{\circ} \mathrm{C}$ was used both as base temperature in the PTR-calculations and for vernalization in this study, based on similar work in other species. Temperature sensitivity of biomass increase in this species should be addressed in further experiments.

An experiment with A. cepa (Brewster 1985) showed a somewhat larger effect of joint temperature and $P P F$ conditions before vernalization on subsequent flowering compared with the relatively minor differences reported in other studies. Leaf number initiated after transfer to vernalizing conditions was reduced in both cultivars studied under high PTR. Plant size after the PTR treatments did not contribute to the leaf number reduction. Also, the plants at high temperature received a shorter growth period, correcting for different developmental rates, as

Table 4. Percentage of generative Salvia $\times$ superba 'Blaukönigin' plants and number of plants that reverted to vegetative growth in relation to vernalization $\left(0\right.$ or 6 weeks at $\left.5{ }^{\circ} \mathrm{C}\right)$ and number of days at elevated PPF $\left(200 \mu \mathrm{mol} \cdot \mathrm{m}^{-2 \cdot} \cdot \mathrm{s}^{-1}\right)$ in subsequent inductive 20 -h long days. Values represent mean \pm SE. After $0,4,7,10$, or $14 \mathrm{~d}$ at $200 \mu \mathrm{mol} \cdot \mathrm{m}^{-2} \cdot \mathrm{s}^{-1}$, the plants were moved to $50 \mu \mathrm{mol} \cdot \mathrm{m}^{-2} \cdot \mathrm{s}^{-1}$ to complete the floral development.

\begin{tabular}{|c|c|c|c|c|}
\hline \multirow{2}{*}{$\begin{array}{l}\text { Long days at } \\
200 \mu \mathrm{mol} \cdot \mathrm{m}^{-2} \cdot \mathrm{s}^{-1} \\
\text { (no.) }\end{array}$} & \multicolumn{2}{|c|}{ Generative plants (\%) } & \multicolumn{2}{|c|}{ Abortion (\%) } \\
\hline & No cold & 6 weeks of cold & No cold & 6 weeks of cold \\
\hline 0 & --- & $20.0 \pm 21.1 \mathrm{~b}$ & --- & $20.0 \pm 21.1 \mathrm{a}$ \\
\hline 4 & $30.0 \pm 24.2 \mathrm{c}^{\mathrm{w}}$ & $40.7 \pm 25.0 \mathrm{~b}$ & $20.0 \pm 15.8 \mathrm{a}$ & $25.9 \pm 22.3 \mathrm{a}$ \\
\hline 7 & $15.0 \pm 18.3 \mathrm{c}$ & $33.3 \pm 24.4 b$ & $5.0 \pm 11.2 \mathrm{a}$ & $20.0 \pm 20.7 \mathrm{a}$ \\
\hline 10 & $25.0 \pm 22.4 \mathrm{c}$ & $62.5 \pm 25.0 \mathrm{ab}$ & $12.5 \pm 17.1 \mathrm{a}$ & $18.8 \pm 20.2 \mathrm{a}$ \\
\hline 14 & $64.7 \pm 24.6 b$ & $100.0 \pm 0.0 \mathrm{a}$ & $36.8 \pm 24.8 \mathrm{a}$ & $33.3 \pm 25.8 \mathrm{a}$ \\
\hline Until flowering & $100.0 \pm 0.0 \mathrm{a}$ & $100.0 \pm 0.0 \mathrm{a}$ & $0.0 \pm 0.0 \mathrm{a}$ & $0.0 \pm 0.0 \mathrm{a}$ \\
\hline
\end{tabular}

${ }^{2}$ Mean separation in columns by Student-Newman-Keuls test at $P \leq 0.05$. 
we did in our experiment with $S$. xsuperba. The temperature was higher and the $P P F$ lower in our experiment compared with Brewster's study. Nevertheless, our results indicate that even if $S$. xsuperba is clearly vernalization-sensitive it does not share such a photothermal response as A. cepa. However, in A. cepa, it is unclear whether the low temperature effect on flowering is vernalizing, or of inductive character. Per definition, vernalization enables the plant to respond to subsequent floral stimuli separately from the actual flower initiation (Lang, 1965). Low temperature induction on the other hand, when plants must remain at low temperatures until flower primordia or flower buds are actually formed in order to complete the flowering process, is known for a few species and is technically not a vernalization effect (Lang, 1965). Furthermore, in, for instance, Pharbitis nil Chois., flowering may be induced in noninductive photoperiods by either low temperature or high light level through what is reported to be a stress response involving salicylic acid signaling (Hatayama and Takeno, 2003; Hirai et al., 1994). Allium cepa might react in a similar manner, in which case the $16^{\circ} \mathrm{C} / 600 \mu \mathrm{mol} \cdot \mathrm{m}^{-2} \cdot \mathrm{s}^{-1}$ scenario would promote flowering over the $26^{\circ} \mathrm{C} / 200 \mu \mathrm{mol} \cdot \mathrm{m}^{-2} \cdot \mathrm{s}^{-1}$ treatment. Six hundred $\mu \mathrm{mol} \cdot \mathrm{m}^{-2} \cdot \mathrm{s}^{-1}$ is considerably higher than the inductive high light level used in P. nil (Hirai et al., 1994).

EFFECT OF VERNALIZATION AND PPF DURING INDUCTIVE LONG DAYS ON FLOWERING. There was a slightly higher LUR under the highest PPF treatment in Expt. 1, which represents a calculated increase of two leaves, based on average FT data from the two $P P F$ treatments. This may be caused by the modest temperature difference of $0.07^{\circ} \mathrm{C}$ between the two $P P F$ levels. However, temperature sensitivity of floral evocation in $S$. ×superba 'Blaukönigin' has not been investigated.

Although there was no macroscopically visible leaf development during cold treatments, it is possible that the vernalization temperature used $\left(5^{\circ} \mathrm{C}\right)$ supports further differentiation of leaf primordia in this species. Throughout both experiments, vernalized plants generally developed more leaves during forcing compared with unvernalized plants, irrespective of $P P F$ treatments. Thus, further leaf differentiation during the vernalization period would reduce the vernalization effect on leaf number reported in these experiments.

The promotion of flowering by vernalization and light level during inductive long days reported in both Expt. 1 and Expt. 2 is in agreement with our findings in an earlier experiment, suggesting the existence of a specific $P P F$-dependent flowering pathway in this vernalization-responsive species. The results from Expt. 1 and Expt. 2 reported here confirm this theory. PPF and low-temperature vernalization each appear to activate differing pathways to flowering in this species. The vernalization-dependent pathway bypasses the effect of $P P F$; thus, the $P P F$-dependent pathway is redundant after a saturating vernalization treatment.

As seen in Expt. 2, the leaf number at flowering did not decline in relation to increasing number of long days at $200 \mu \mathrm{mol} \cdot \mathrm{m}^{-2 \cdot} \mathrm{s}^{-1}$ during the first 2 weeks of inductive long days, but evocation was significantly promoted as the period of time at the highest $P P F$ was extended until anthesis. Thus, without a preceding cold treatment it seems that the plants are able to flower at an early developmental stage provided they receive high $P P F$ during a relatively narrow time frame at the time of floral evocation. The time of evocation seems to be uninfluenced by ambient $P P F$ during vegetative growth earlier in the long-day period. Alternatively, there may be a cumulative effect of the highest $P P F$ on floral evocation. The designated number of days at the highest $P P F$ was based on apex dissection in a preliminary experiment using the same temperature and $P P F$ settings. In Expt. 2, an average of six more leaves developed before evocation when the highest PPF was continued until anthesis, compared with our experience from other trials. Since we also experienced unusually low flowering percentage at the lower $P P F$ in addition to this delayed evocation at the highest $P P F$, we are led to believe that this is connected to the particular seed lot rather than experimental treatments, something which should be addressed if further tests to fully establish the sensitivity of evocation to $P P F$ in unvernalized $S$. $\times$ superba plants are initiated.

The frequent reversion to vegetative growth, resulting in blind shoots, observed at the lower PPF level in Expt. 2 indicates that the light level and duration is significant for the early development of floral primordia as well as evocation. Abortion of flower buds under low PPF has been previously reported. Mor and Halevy (1980) attributed blindness in Rosa hybrida L. 'Marimba'blasting to reduced sink strength and insufficient assimilate supply to the growing flower bud. The same light levels and photoperiods were used in this experiment as in previous trials in which blasting did not occur. We did not record any other conditions that would explain the occurrence of blasting in this experiment. Bodson et al. (1977) found that high light levels also promoted the transition to flowering in Sinapis alba L. The effect was primarily connected with enhanced photosynthesis. However, further experiments with $\mathrm{CO}_{2}$ free air and sucrose applications suggest an additional effect of light on an unknown process other than carbon assimilation (Bodson et al., 1979). Moreover, in florally induced S. alba plants, an increase in sucrose supply to the apex has been recorded early in the evocation process, which seems to be associated with mobilization of stored assimilates and thus separate from ongoing photosynthesis (Lejeune et al., 1991, 1993). There is a possibility that the promotion of evocation observed in unvernalized $S$. $\times$ superba plants in response to a higher PPF level is caused by apex supply of sucrose from stored assimilates in a similar manner as with $S$. alba. When applying various $P P F$ treatments during a single inductive long day in $S$. alba, Bodson et al. (1977) found that the flowering response to a high light level was dependent on the specific timing of the treatment rather than overall duration. Hence, the enhanced flowering seen in $S$. alba might be a response to ambient $P P F$ received by the plant during a specific step in the evocation process, rather than a reaction to overall DLI. Whether the flowering response to ambient light level seen in $S$. ×superba is dependent on total duration or specific timing of the $P P F$ treatment was not investigated in our study.

\section{Concluding Remarks and Summary}

Increasing the light level in relation to temperature generally enhances immediate net photosynthesis and will over time increase the amount of stored assimilates in plants. However, in Expt. 1 we have shown that floral evocation in $S$. ×superba is unaffected by different PTR treatments applied over several weeks preceding the inductive long-day treatment. This does not necessarily exclude involvement of stored assimilates in the promotion of flowering in $S$. xsuperba by high $P P F$, however, since the floral promotion might still be mediated through the process of starch mobilization or phloem transport. Moreover, net photosynthesis was not measured in this experiment. Nevertheless, our results from Expt. 2 suggest that the reduced time to evocation (LN) seen in unvernalized plants by specifically increasing the light 
level is dependent on the $P P F$ during the actual evocation process and not during preceding vegetative growth. This implies that assimilate accumulation prior to evocation is not essential for the $P P F$ response, provided of course that the light level exceeds the compensation point and supports further growth as in our experiments.

In summary, our results support the existence of a $P P F$-dependent pathway for floral evocation in unvernalized plants of $S$. $\times$ superba 'Blaukönigin', indicated by earlier experiments with this species (G. Waaseth, R. Moe, and S.O. Grimstad, unpublished). The $P P F$ effect is bypassed after a saturating vernalization treatment. Inflorescence development is equally dependent on sufficient $P P F$ supply, irrespective of which flowering pathway facilitates floral evocation. Although visual assessment showed that young plant size and quality improved with increasing PTR, practically no effect can be seen on subsequent floral evocation in $S$. ×superba from a high PTR prior to vernalization. The observed PPF effect on the onset of evocation in unvernalized plants seems to be dependent on ambient light level (either incident PPF or DLI) at the actual time of evocation, irrespective of light level during preceding growth. Further experiments are needed to establish the underlying mechanism. One possibility is that increased assimilate transport to the apex promotes floral evocation, either through a high rate of photosynthesis or rapid mobilization of stored assimilates.

\section{Literature Cited}

Bagnall, D.J. 1992. Control of flowering in Arabidopsis thaliana by light, vernalization and gibberellins. Austral. J. Plant Physiol. 19:401-409.

Bodson, M., G. Bernier, J.M. Kinet, A. Jacqmard, and A. Havelange. 1979. Flowering of Sinapis as influenced by different treatments acting on photosynthetic activity, p. 73-82. In: R. Marcelle, H. Clijsters, and M. van Poucke (eds.). Photosynthesis and plant development. W. Junk, The Hague, The Netherlands.

Bodson, M., R.W. King, L.T. Evans, and G. Bernier. 1977. The role of photosynthesis in flowering of the long-day plant Sinapis alba. Austral. J. Plant Physiol. 4:467-478.

Brewster, J.L. 1985. The influence of seedling size and carbohydrate status of photon flux density during vernalization on inflorescence initiation in onion (Allium cepa L.). Ann. Bot. 55:403-414.

Cremer, F., A. Havelange, H. Saedler, and P. Huijser. 1998. Environmental control of flowering time in Antirrhinum majus. Physiol. Plant. 104:345-350.

Hatayama, T. and K. Takeno. 2003. The metabolic pathway of salicylic acid rather than of chlorogenic acid is involved in the stress-induced flowering of Pharbitis nil. J. Plant Physiol. 160:461-467.

Hirai, N., M. Yamamuro, K. Koshimizu, M. Shinozaki, and A. Takimoto. 1994. Accumulation of phenylpropanoids in the cotyledons of morning glory (Pharbitis nil) seedlings during the induction of flowering by low temperature treatment, and the effect of precedent exposure to high-intensity light. Plant Cell Physiol. 35:691-695.

Lang, A. 1965. Physiology of flower initiation, p. 1380-1536. In: W. Ruhland (ed.). Encyclopedia of plant physiology. Vol. XV. Differentiation and development. Springer-Verlag, Berlin.

Lejeune, P., G. Bernier, and J.M. Kinet. 1991. Sucrose levels in leaf exudate as a function of floral induction in the long day plant Sinapis alba. Plant Physiol. Biochem. 29:153-157.

Lejeune, P., G. Bernier, M.C. Requier, and J.M. Kinet. 1993. Sucrose increase during induction in the phloem sap collected at the apical part of the shoot of long-day plant Sinapis alba L. Planta 190:71-74.

Liu, B. and R.D. Heins. 1998. Modeling poinsettia vegetative growth and development: The response to the ratio of radiant to thermal energy. Acta Hort. 456:133-142.

Liu, B. and R.D. Heins. 2002. Photothermal ratio affects plant quality in 'Freedom' poinsettia. J. Amer. Soc. Hort. Sci. 127:20-26.

Mor, Y. and A.H. Halevy. 1980. Promotion of sink activity of developing rose shoots by light. Plant Physiol. 66:990-995.

Napp-Zinn, K. 1960. Vernalization, Licht und alter bei Arabidopsis thaliana (L.) Heynh. II. Planta 54:445-452.

Napp-Zinn, K. 1984. Light and vernalization, p. 75-88. In: D. VincePrue, B. Thomas, and K.E. Cockshull (eds.). Light and the flowering process. Academic Press, Orlando, Fla.

Niu, G., R.D. Heins, A.C. Cameron, and W.H. Carlson. 2002. Prevernalization daily light integral and vernalization temperature influences flowering of herbaceous perennials. HortScience 37:1028-1031.

Pierik, R.L.M. 1967a. Effect of light and temperature on flowering in Cardamine pratensis L. Zeitschrift für Pflanzenphysiologie 56:141-152.

Pierik, R.L.M. 1967b. Regeneration, vernalization and flowering in Lunaria annua L. in vivo and in vitro. Publ. 295. Communications, Agricultural Univ., Wageningen, The Netherlands. 